\title{
Prey-Driven Behavioral Habitat Use in a Low-Energy Ambush Predator
}

Annalee M. Tutterow, Andrew S. Hoffman, John L. Buffington, Zachary T. Truelock, and William E. Peterman

School of Environment and Natural Resources, The Ohio State University, 2021 Coffey Rd, 210 Kottman Hall, Columbus, OH 43210, USA

Correspondence: Annalee M. Tutterow; Email: antutterow@gmail.com

\section{Abstract}

1. Food acquisition is an important modulator of animal behavior and habitat selection that can affect fitness. Optimal foraging theory predicts that predators should select habitat patches to maximize their foraging success and net energy gain, which predators can achieve by targeting spaces with high prey availability. However, it is debated whether prey availability drives fine-scale habitat selection for predators.

2. We assessed whether an ambush predator, the timber rattlesnake (Crotalus horridus), exhibits optimal foraging site selection based on the spatial distribution and availability of prey.

3. We evaluated the spatial concordance of radio-telemetered timber rattlesnake foraging locations and passive infrared game camera trap detections of potential small mammal prey (Peromyscus spp., Tamias striatus, and Sciurus spp.) in a mixed-use forest in southeastern Ohio from 2016-2019. We replicated a characteristic timber rattlesnake ambush position by focusing cameras over logs and modeled small mammal encounters across the landscape in relation to remotely-sensed forest and landscape structural features. To determine whether snakes selectively forage in areas with higher prey availability, we projected the estimated prey spatial relationships across the landscape 
and modeled their overlap of occurrence with observed timber rattlesnake foraging locations.

4. We broadly predicted that prey availability was greatest in mature deciduous forests, but T. striatus and Sciurus spp. exhibited greater spatial heterogeneity compared to Peromyscus spp. We also combined predicted species encounter rates to encompass a body size gradient in potential prey. The spatial distribution of cumulative small mammal encounters (i.e. overall prey availability), rather than the distribution of any one species, was highly predictive of snake foraging.

5. Timber rattlesnakes appear to select foraging locations where the probability of encountering prey is greatest. Our study provides evidence for fine-scale optimal foraging in a low-energy, ambush predator and offers new insights into drivers of snake foraging and habitat selection.

\section{Keywords}

38 Ambush hunting, Camera traps, Habitat use, Optimal foraging, Prey availability, Site selection,

39 Small mammals, Timber rattlesnakes 
Animal activity patterns are governed by the acquisition of spatially and temporally

41 variable resources from the landscape, such as food, mates, shelter, or hospitable environmental

42 conditions. Successfully procuring food is particularly essential for individual survival, growth,

43 reproduction, and ultimately fitness (Tetzlaff et al., 2017). Therefore, it is important to link the

44 distribution and availability of food with an animal's space use to better understand the drivers of

45 movement and habitat selection (Heard et al., 2004; Williams et al., 2013).

Given the fitness trade-offs of investing time and/or energy into one behavior instead of

47 another (Beaupre, 2008; Glaudas \& Alexander, 2017), optimal foraging theory predicts that

48 predators should forage where they will have the greatest success (i.e. net energy gain; Charnov

49 1976). More explicitly, the ideal free distribution (IFD) predicts that predators should disperse to

50 patches proportional to their food abundance (Flaxman \& Lou, 2009; Williams et al., 2013).

51 Predators can achieve IFD by either tracking prey densities or environmental gradients in prey

52 foraging habitat (Flaxman \& Lou, 2009; Kittle et al., 2017). Under game theory predictions,

53 predators are expected to aggregate in areas where prey are abundant at large spatial scales but

54 less precisely match prey distributions at fine scales (Hammond et al., 2012). Accordingly,

55 wolves (Kittle et al., 2017), sea lions (Womble et al., 2009), and snakes (Madsen \& Shine, 1996)

56 have all been documented selecting habitats with higher prey availability at broad (regional or

57 macrohabitat) scales.

A complication to understanding drivers of foraging behavior is that habitat selection can

59 be multi-scale and hierarchical (Johnson, 1980; Mayor et al., 2009). Predators can demonstrate

60 hierarchical foraging behavior as a result of multiple scale-dependent processes, such as

61 predation risk or resource availability (McNeill et al., 2020). Conversely, observed foraging

62 patterns can result from predominantly fine-scale resource selection (Harvey \& Weatherhead, 
63 2006). The space use of ectotherms is often driven by microhabitat conditions that affect their

64 ability to thermoregulate, avoid predation, and forage (Harvey \& Weatherhead, 2006; Sutton et

65 al., 2017). Therefore, snakes may not distribute themselves proportionally to prey availability

66 (i.e. achieve IFD) nor forage optimally if prey-rich patches do not coincide with optimal

67 environmental conditions for thermoregulation (Blouin-Demers \& Weatherhead, 2001; Carfagno

68 et al., 2006).

Indeed, some studies have found no evidence of snakes selecting prey-rich areas

70 (Carfagno et al., 2006; Sperry \& Weatherhead, 2009; Michael et al., 2014). However, other

71 studies have found mixed or scale-dependent support for prey-mediated habitat selection by

72 snakes (Whitaker \& Shine, 2003; Glaudas \& Rodríguez-Robles, 2011). Multi-scale studies

73 emphasize the importance of habitat structure coinciding with prey availability for snake habitat

74 selection (Heard et al., 2004; Glaudas \& Rodríguez-Robles, 2011). Therefore, whether snakes

75 exhibit IFD characteristics or optimally forage remains unresolved. Investigating the spatial

76 overlap of snakes and their prey is essential to understand potential drivers of foraging behavior

77 and habitat selection.

One hypothesis for the spatial overlap of snakes and their small mammal prey is that

79 similar habitat preferences drive spatial interaction (Blouin-Demers \& Weatherhead, 2001).

80 Snakes therefore select habitat based on thermoregulation or other habitat requirements and

81 opportunistically forage, which has been observed in generalist predators such as ratsnakes

82 (Pantherophis spp.) and Eastern racers (Coluber constrictor; Blouin-Demers \& Weatherhead,

83 2001; Carfagno et al., 2006). Snakes that opportunistically forage may have home ranges

84 containing high prey densities, but they may not exhibit fine-scale selection that maximizes

85 potential prey encounters (Sperry \& Weatherhead, 2009). An alternative hypothesis is that the 
86 spatial distribution of prey abundance drives snake habitat selection (Blouin-Demers \&

87 Weatherhead, 2001). Prey-mediated habitat selection suggests greater alignment of snake space

88 use with prey availability (i.e. demonstrating IFD). This pattern is more likely to be evident in

89 dietary specialists (Madsen \& Shine, 1996) or during times of environmental stress such as

90 drought (Whitaker \& Shine, 2003).

91 Although some studies support contrasting hypotheses, not all studies used effective

92 metrics for assessing prey distributions and snake site selection. First, most studies are conducted

93 on a macrohabitat scale, which may not be appropriate when investigating snake habitat selection

94 (Harvey \& Weatherhead, 2006). Additionally, researchers typically evaluate prey abundance

95 rather than prey availability. Prey abundance may not equate to prey availability when factors

96 affecting prey detection are not considered (Sperry \& Weatherhead, 2009; Reinert et al., 2011).

97 Specifically, prey may be more abundant in some habitat types but more easily detected by the

98 predator in others (i.e. higher catchability; Hopcraft et al., 2005). To our knowledge, no study

99 has estimated prey availability for snakes at a fine scale and assessed prey distributions as a

100 driver of snake foraging site selection.

The paucity of studies examining prey availability at a fine scale may be due to the

102 logistical challenges of determining the exact microhabitats where the predator forages (Glaudas

103 \& Rodríguez-Robles, 2011). However, rattlesnake natural history characteristics make them

104 ideal subjects to test hypotheses related to optimal foraging theory. We sought to determine

105 whether foraging site selection of timber rattlesnakes (Crotalus horridus; hereafter TRS), is

106 related to the availability of prey on a fine scale. 
109 orient their head perpendicular to the long axis of a log or other downed wood while maintaining

110 a tight body coil (Reinert et al., 2011). The species' conspicuous foraging behavior allows for

111 identification of exact foraging sites. In addition, TRS feed almost exclusively on small

112 mammals, primarily shrews (Soricidae), voles (Cricetidae), mice in the genus Peromyscus,

113 chipmunks (Tamias striatus), and squirrels (primarily Sciurus carolinensis; Clark, 2002). This

114 relatively narrow dietary breadth reduces the potential for complex interactive or conflicting

115 relationships between primary prey, alternative prey and TRS foraging preferences (Carfagno et

116 al., 2006).

117 Our multi-year radio-telemetry study provided a behaviorally and spatially explicit

118 dataset of TRS activity that allowed us to differentiate among behavior-specific site use and

119 account for individual variation in foraging site selection. The primary goals of our study were to

120 define small mammal spatial distributions and their overlap with observed TRS foraging

121 locations at a fine spatial scale to determine whether TRS optimally forage in prey-rich areas.

122 Our approach entailed (1) quantifying small mammal relative availability with widely-distributed

123 camera traps, (2) projecting small mammal encounters across the study area with landscape

124 predictors, and (3) using radio-telemetry-derived TRS behavioral data and the spatially

125 continuous prey encounter surface to assess the predictive strength of prey availability on TRS

126 foraging site selection.

\section{Methods}

\section{Study Site}

We conducted our study within a mixed-use forest landscape (approximately 5,000 ha) in

130 southeastern Ohio. Vinton Furnace Experimental Forest (VFEF) consists primarily of second- 
131 growth forests punctuated by early-successional stands managed through various silvicultural

132 and management practices (ODNRF, 2020). Forest communities in the region vary along

133 topographic gradients. Ridgetops and southwestern-facing slopes are dominated by mixed oak

134 (Quercus spp.) and hickory (Carya spp.) assemblages and shrubby (Vaccinium spp.) understory.

135 Northeastern-facing slopes and river bottoms harbor mesophytic taxa such as Acer rubrum, Acer

136 saccharum, and Ulmus rubra (Adams \& Matthews, 2019).

\section{Camera trap design}

Timber rattlesnakes hunt along logs (Reinert et al., 1984) and these microhabitats are also

139 used by small mammals as "runways" (Douglass \& Reinert, 1982; Fig. 1). To simulate this

140 foraging behavior, we fixed passive infrared game cameras (Moultrie M-888) to metal fence

141 posts approximately one meter above-ground and positioned them directly overlooking the

142 nearest $\log (>15 \mathrm{~cm}$ diameter) at each site (Fig. 2). We placed a canister with small holes that

143 contained peanut butter under each camera. Our camera deployment protocol allowed us to

144 obtain fine-scale rodent encounter rates, which we considered more informative of prey

145 availability for TRS than representative macrohabitat-scale estimates of rodent abundance

146 (Reinert et al., 2011).

147 We deployed game cameras from 2017-2018 at 242 randomly-chosen, unique sites. We

148 stratified these random points across the dominant macrohabitat types (deciduous forest, pine

149 plantations, clear cuts, and burns) to ensure adequate sampling of each land cover type

150 proportional to its prevalence on the landscape. Accordingly, we sampled more sites from

151 deciduous forests (representing approximately $80 \%$ of the landscape) than any other forest type

152 (Table S1). We also set 26 camera traps at previously noted TRS foraging locations. We placed 
153 this subset of cameras at observed foraging sites between a day to a few weeks (range 1-86 d;

154 median $15 \mathrm{~d}$ ) of the snake's departure from the site.

Game camera active intervals varied by site. We set game cameras at sites for 3-51 days

156 (mean $7.3 \mathrm{~d}$; median $6 \mathrm{~d}$ ) between 15 June and 13 October 2017 and 4-22 days (mean $8 \mathrm{~d}$;

157 median 6 d) between 24 May and 26 September 2018. We focused our analysis on likely prey

158 items for TRS that were also consistently captured on camera: white-footed/deer mice

159 (Peromyscus leucopus/maniculatus), eastern chipmunks (Tamias striatus), and eastern gray

160 squirrels/fox squirrels (Sciurus carolinensis/niger). We monitored occupancy (presence/absence)

161 of each species during observation windows of roughly 12-hr day (approximately 0700-2000 h)

162 and night (approximately $2100-0600 \mathrm{~h}$ ) periods. We therefore did not track the number of

163 individuals present during each observation period. Because night intervals spanned two dates,

164 we considered small mammals active in the early morning (e.g., before $0600 \mathrm{~h}$ ) as present in the

165 night interval of the previous date.

Landscape variables characterizing small mammal distributions

Habitat selection for small mammals, particularly as it relates to forest structural features,

168 is typically assessed with microhabitat and vegetation structural characteristics, such as coarse

169 woody debris and leaf litter cover (Nelson et al., 2019). However, it was not feasible to assess

170 microhabitat features for each camera location and across the landscape. Airborne light detection

171 and ranging (LiDAR) can describe horizontal and vertical vegetation structure across large areas,

172 providing a valuable alternative to the use of intensive field-based methods to assess forest

173 structure (Simonson et al., 2014). Schooler and Zald (2019) demonstrated that LiDAR-derived

174 metrics are effective predictors of small mammal diversity in a temperate mixed-forest 
175 community. We therefore used LiDAR and other remotely sensed data to quantify forest structure and predict small mammal occupancy across the landscape.

We described landscape composition and structure at each camera location with 16 land-

179 for our study area (Table 1). Stand-level forest management data, including burn history and

180 stand age, reflect active management at VFEF by the Ohio Division of Forestry and U.S. Forest

181 Service over the past 60 years. We derived topographic variables, such as Beers' aspect (Beers et

182 al., 1966), slope, and elevation from a LiDAR digital terrain model (DTM). To describe forest

183 composition, we considered compositional, multivariate metrics (NMDS1 and NMDS2) that

184 allowed for continuous variation across the landscape. Adams et al., (2019) combined a LiDAR-

185 derived DTM, vegetational plot data, and Landsat 8 OLI imagery to generate floristic gradients

186 for the study area. We sourced the LiDAR-derived DTM from The Ohio Geographically

187 Referenced Information Program (OGRIP; https://ogrip.oit.ohio.gov/Home.aspx) and Landsat 8

188 Imagery from the United States Geological Survey (USGS; https://earthexplorer.usgs.gov), and

189 corrected for known timber harvests occurring after data acquisition (Adams \& Matthews, 2018;

190 Adams et al., 2019). We tested for multicollinearity among the predictors with Pearson's

191 correlation coefficient, and no variables were correlated above 0.7. We scaled and centered all

192 continuous variables to have a mean of zero and standard deviation of one.

\section{Timber rattlesnake radio-telemetry}

As part of an ongoing study, we radio-tracked 37 adult TRS (21 males and 16 non-gravid

195 females) between 2016 and 2019 to obtain behavior-specific spatial data (further described in

196 Hoffman et al., 2020, in review). We relocated snakes 1-3 times per week and classified

197 behavioral state (e.g., ecdysis, resting, foraging) upon relocation, resulting in 522 observed 
198 foraging locations. We noted foraging locations when snakes exhibited a characteristic "S"-

199 shaped ambush posture: compactly coiled, with head extending past outer coil, and a greater

200 number of anterior directional changes compared to a resting state (Fig. 1; Reinert et al., 1984).

201 We also identified the presumed foraging orientation type-log-oriented, non-log-oriented, or

202 vertical-tree-oriented (Reinert et al., 2011; Goetz et al., 2016). We defined a log-oriented posture

203 as when snakes rested on or faced (within 1-m) a log or fallen branch (Fig. 1A; Reinert et al.,

204 1984). We defined a vertical-tree-oriented posture as when snakes coiled at the base of standing

205 trees, with their heads oriented upwards or facing (within 1-m) a tree (Fig. 1C; Goetz et al.,

206 2016). We considered snakes coiled in ambush on the forest floor but not log or vertical-tree-

207 oriented to be in a non-log-oriented posture (Fig. 1B; Reinert et al., 2011). We found males and

208 non-gravid females in our study equally likely to forage log-oriented ( $\mathrm{n}=244)$ as non- $\log$ -

209 oriented $(n=239)$, and to rarely exhibit a vertical-tree-orientation $(n=39)$. A preliminary

210 analysis showed that foraging orientation type did not affect prey encounter rate for any prey

211 species (Fig. S1). We therefore included all foraging location types in the Snake Foraging

212 Probability models to assess snake foraging spatial concurrence with prey availability.

\section{Small mammal encounter rate models}

We modeled the number of days/nights with a small mammal species' observation using

215 Bayesian zero-inflated generalized linear models (GLM). We considered a zero-inflated

216 framework because of the coarse sampling of small mammals across our site and resulting

217 overdispersion in counts. Ecological datasets often contain a higher frequency of measured zeros

218 than can be accommodated by standard statistical distributions and can therefore violate the

219 assumptions of these distributions (Martin et al., 2005). Zero-inflated models combine two

220 underlying processes, modeling non-zero counts and true zeros with a Poisson or negative 
221 binomial process and the potentially false zeros with a binomial process $(\mathrm{Zi})$, generating the

222 probability of measuring a zero in error (Zuur et al., 2009).

We tested the global set of landscape covariates $(n=16)$, year, an offset of the number of

224 active camera days, and $Z i$ covariates (i.e. the binomial "false-zero" process) under negative

225 binomial and Poisson distributions, resulting in 10 candidate global models for each species

226 (Tables S2-S4). We suspected that interannual variation, likely representing acorn mast

227 availability (Clotfelter et al., 2007), or the timing of camera placement during each season (i.e.

228 seasonal fluctuations in small mammal activity patterns) could affect our detection success at a

229 particular location. We therefore accounted for temporal variation in species encounter rates for

230 zero-inflated models with the $Z i$ term, using no covariates as a null, median date of camera

231 deployment (modeled as a quadratic function), year, and the additive or interactive combinations

232 of median date and year (Tables S2-S4). We used diagnostic plots to compare each model's

233 predictions of the mean and variance and selected the global model of best fit. For each small

234 mammal species, a zero-inflated negative binomial model best represented encounters but the

235 selected $Z i$ covariates varied by species (Table S5).

We examined model coefficients for their magnitude of effect in each selected global

237 model and removed covariates with no or a negligible effect, removed covariates with $>15 \%$

238 posterior distribution overlap with zero, and removed covariates with $>20 \%$ of the posterior

239 within the Region of Practical Equivalence (ROPE; Piironen \& Vehtari, 2017). We considered

240 the resulting species model with the lowest leave-one-out statistic (LOO) and Watanabe-Akaike

241 Information Criterion (WAIC) value to be the most parsimonious. 
244 'raster' package in R version 3.6.1 (Hijmans 2020; R Core Team 2020). We generated mean

245 encounter probabilities for each species across the study site at a 10-m resolution for 2017 and

246 2018. In addition to landscapes of species-specific encounter rates, we considered the dietary

247 breadth of adult TRS, and generated grouped prey landscapes by adding the relevant encounter

248 surfaces together. In one group, we combined mouse and chipmunk encounters (Cumulative

249 MC) because they are most likely to be encountered at logs (Douglass \& Reinert, 1982). We also

250 combined mouse, chipmunk and squirrel encounters (Cumulative Prey) to capture the body size

251 gradient in prey selection for adult TRS. We extracted the predicted prey species or prey group

252 encounter rates at every TRS location.

\section{Snake foraging models}

We modeled snake foraging using mixed-effects Bernoulli GLMs with foraging behavior

255 as a binomial function of the spatially-explicit small mammal encounter rates. We included a

256 random effect for individual snakes. We tested models with prey type variations for non-gravid

257 adult females (NGF; $n=16)$, adult males $(n=21)$, and the combined adult TRS group $(n=37)$.

258 We excluded gravid females $(\mathrm{n}=10)$ because they fast during gestation (Reinert et al., 1984).

We did not monitor small mammal spatial distributions for two years (2016 and 2019)

260 that we tracked snakes. Although we recognize the potential for prey fluctuations in density

261 corresponding with acorn mast cycles (Clotfelter et al., 2007), the predictive landscape metrics

262 we considered did not vary over the course of the study. We therefore generalized our findings

263 from 2017-2018 to all observations from our telemetry study. We estimated small mammal

264 encounter rates, comprising mouse, chipmunk, squirrel, and the cumulative prey surfaces

265 (Cumulative MC and Cumulative Prey) for 2017 and 2018, but used the two-year averaged

266 encounter rates for each species or species group to represent prey availability in 2016 and 2019. 
267 We report results from 2016-2019 but reference the 2017-2018 subset in model selection tables

268 and when applicable in results (see supplementary material for further details). We tested

269 species-level and cumulative prey models for adults collectively, and non-gravid females and

270 males separately. We considered the foraging models with the lowest LOO and WAIC scores as

271 the best-supported model for each group. We used the 'brms' package in R to fit all statistical

272 models (Bürkner, 2017).

273 Results

274

Prey diversity on camera traps

Across 242 camera sites and a cumulative 1901 trap days and 1662 trap nights, we successfully captured the dominant prey species of TRS. We detected mice at most sites (61\% of

277 sites with $\geq 1$ detection; Table 2 ) and the most extensively and frequently (range of $0-17$ camera 278 days) of any species. We observed chipmunks and squirrels at fewer sites (<50\% of sites) and 279 less frequently (maximum of 9 and 6 days, respectively; Table 2). In addition to these primary 280 prey items, we also infrequently captured shrews (Soricidae), voles (Microtus spp.), and 281 cottontail rabbits (Sylvilagus floridanus). We also frequently captured bird species that are 282 potential opportunistic prey sources.

\section{Small mammal encounter rate models}

284 Mice - The most explanatory model for daily mice encounters was a zero-inflated $(\mathrm{Zi}=$

285 year) negative binomial model with year, burn history, and stand age (Table S5). Mice were most

286 likely to be encountered in non-burns of a younger age (Table 3). Mice were encountered

287 approximately twice as frequently in 2018 (2.22 mice/day; 95\% CI: 1.94-2.55) than 2017 (0.91

288 mice/day; 95\% CI: 0.70-1.16; Fig. 3A). Encounters were lowest in burned stands (Table 3), at 
0.53 mice encounters per day compared to approximately 0.91 encounters/day in other stand types (Fig. 3B). Stand age was the weakest predictor of mice encounters (Table 3), but

291 encounters were generally more frequent in younger stands (Fig. 3C). Mice could be encountered 292 across the landscape at a range of $0.32-0.81 /$ day in 2017 and $0.84-1.9 /$ day in 2018.

Chipmunks - The best-fitting model for daily chipmunk (CM) encounters was a zero-

294 inflated $(Z i=$ year $)$ negative binomial model with the forest successional gradient (NMDS2),

295 plant species richness (PSR), and slope (Table S5). Chipmunks were most frequently

296 encountered in stands with taller canopies and greater plant richness, and along steeper slopes

297 (Fig. 4). The forest successional gradient was the best landscape predictor (Table 3) of chipmunk

298 encounter rates (Fig. 4A). Encountering a chipmunk would take between 1-2.5 days (mean $~ 1.5$

299 days) in a more mature forest but between 3-16 days (mean 7 days) in a younger stand. Plant

300 species richness had a similar effect size (mean $0.23 \pm 0.11)$, increasing from $0.14 \mathrm{CM} / \mathrm{day}(95 \%$

301 CI: 0.04-0.40) at low plant richness to an estimated 0.74 CM/day (95\% CI: 0.37-1.48) in a more

302 speciose stand (Fig. 4B). Chipmunks were also encountered more frequently along steeper slopes

303 (Fig. 4C). Chipmunks could be encountered across the landscape at a range of 0.01-1.2/day in

3042017 and $0.04-2.8 /$ day in 2018.

Squirrels - The most supported model for squirrel (SQ) encounters was a zero-inflated

$\left(Z i=\right.$ median date ${ }^{2}+$ year) negative binomial model with year, foliage height diversity (FHD),

307 the moisture gradient (NMDS1), NMDS2, overstory density, and understory density (Table S5).

308 Squirrels were most frequently encountered in drier areas and stands with taller canopies and

309 greater overstory density, low canopy structural diversity, and low understory density (Table 3).

310 Year had the largest effect on squirrel encounters (1.05 \pm SE 0.31), with encounter rate doubling 
311 from an estimated $0.16 \mathrm{SQ} /$ day (95\% CI: 0.08-0.25) in 2017 to $0.37 \mathrm{SQ} /$ day (95\% CI 0.19-0.56)

312 in 2018 (Fig. 5A).

313 The forest succession gradient (NMDS2) was the best landscape predictor of squirrel

314 encounter rates, with squirrels ten times more frequently encountered in forest stands with taller

315 canopies (0.38 encounters/day, 95\% CI: 0.15-0.93) compared to early seral stands (Fig. 5B).

316 Squirrels could be encountered within 1-7 days (mean 3 days) in a mature stand versus rarely, if

317 at all, in the youngest stands with low canopy height. Squirrel encounters were negatively

318 associated with NMDS1, suggesting the species' preference for drier, southwestern-facing slopes

319 that harbor nut-bearing trees (Fig. 5C). Squirrel encounter rate drastically declined with greater

320 understory density, from 0.55 SQ/day (95\% CI: 0.17-1.64) in sparse understories to minimal

321 encounters (0.03 SQ/day; 95\% CI: 0.01-0.13) in highly vegetated understories (Fig. 5D).

322 Squirrels were also encountered more frequently at sites with greater overstory density (Fig. 5E).

323 Additionally, squirrels were negatively associated with foliage height diversity (FHD; Fig. 5F),

324 suggesting a preference for forests stands of similar height and age (Aber, 1979). Squirrels could

325 be encountered across the landscape at a range of $0.004-1.29 /$ day in 2017 and $0.01-3.2 /$ day in 3262018.

327 Foraging Probability Models

The Cumulative Prey landscape, representing the overlay of mice, chipmunk, and squirrel

329 daily encounters, was a strong, well-supported predictor (1.09 \pm SE 0.09) of adult TRS foraging

330 probability (Table S6; Table S7). The probability of snake foraging increased sharply with

331 predicted prey encounter rates (Fig. 6). Snake foraging probability increased from a minimum of

3320.06 (95\% CI: 0.04-0.08) associated with an estimated mean prey encounter rate of 0.59

333 prey/day to 0.69 (95\% CI: $0.61-0.76)$ at an estimated 3.83 prey/day (Fig. 6). 
Cumulative Prey was also the best predictor $(1.05 \pm$ SE 0.15$)$ for non-gravid females in

335

336

337

338

339

340

341

342

343

344

345

346

347

348

349

350

351

352

353

354

355

both year groupings (Table S6). Female foraging probability increased from 0.07 (95\% CI: 0.05-

$0.11)$ at low estimated prey encounters ( 0.63 prey/day) to 0.7 (95\% CI: $0.55-0.80)$ at the highest

predicted prey encounter rate (3.8 prey/day; Fig. 7A). In terms of individual prey species, the

best-supported species-level model for females included encounter rates for mice $(1.39 \pm \mathrm{SE}$

$0.22)$ and squirrels $(1.73 \pm$ SE 0.72 ; Table S7), but with a modest increase in foraging probability

associated with mice encounters only (Fig. 7B) and significant uncertainty around the effects of

squirrel encounters only (Fig. 7C).

For males, the species-level foraging model was marginally more supported in 2016-

2019 and the Cumulative Prey model was better-supported in 2017-2018 (Table S6). There was

greater uncertainty around species-level effects on male foraging, particularly for squirrels

(Table S7). The distribution of mice $(0.75 \pm$ SE 0.20$)$ was least predictive of male foraging;

foraging probability increased marginally to 0.3 (95\% CI: $0.22-0.38)$ at the greatest predicted

encounter rate (1.90 mice/day; Fig. 8A). Predicted chipmunk (1.09 \pm SE 0.35) and squirrel (2.9 \pm

SE 0.77) encounters had the greatest effects on male foraging (Table S7). Male foraging

probability increased to a maximum of 0.51 (95\% CI: 0.29-0.72) at the highest chipmunk

encounter rate of $1.81 \mathrm{CH} /$ day (Fig. 8B). For squirrel encounters, male foraging probability

increased sharply to a maximum of 0.62 (95\% CI: $0.36-0.83)$ at high predicted encounters $(0.87$

SQ/day; Fig. 8C). Estimated Cumulative Prey encounters also had a strong effect (1.14 \pm SE

0.11) on male foraging probability, similar to trends observed across all adults (Table S7; Fig.

8D).

Discussion 

snakes in particular can be low-energy specialists (Glaudas \& Alexander, 2017), prey

358 distribution and availability may be considered unlikely proximate influences on habitat

359 selection (Heard et al., 2004; Carfagno et al., 2006). However, we found that total prey

360 'availability' (measured as cumulative daily prey encounter rates), rather than any one prey type,

361 was overall the best predictor of TRS foraging. Our results suggest that TRS may forage

362 optimally and preferably forage in prey-rich areas according with IFD. Further, our study

363 supports that TRS may attune to fine-scale differences in prey availability despite specializing on

364 common woodland rodents that are generally thought to be widespread.

366 across a single, typically macrohabitat scale. The effects of temporal and/or spatial heterogeneity

367 in prey densities on predator habitat selection is also more straightforward to describe on a

368 broader scale because one can estimate prey abundance/availability and describe snake habitat

369 use within specific habitat types (Glaudas \& Rodríguez-Robles, 2011). However, prey may be

370 more abundant in some habitats but more easily detected by the predator in others (i.e. "higher

371 catchability") due to a lack of cover or camouflage or changes to predator avoidance behavior by

372 prey (Hopcraft et al., 2005). For example, TRS in an agricultural landscape frequently foraged in

373 fields that harbored lower densities of small mammals than surrounding woodlands, likely as a

374 result of increased prey catchability (Wittenberg 2012). Because of the use of both 'prey

375 availability' and 'prey abundance' interchangeably in the literature, we will hereafter use prey

376 availability to refer to both but will make note of the context in which they are used when

377 possible. 
Other studies have shown that snake home ranges generally contain a high proportion of

379 habitat preferred by rodents (i.e. correspondingly high rodent densities), but snakes do not

380 exhibit site selection that would maximize small mammal encounters (Sperry \& Weatherhead,

381 2009; Glaudas \& Rodríguez-Robles, 2011; but see Baxley \& Qualls, 2009). We expect that we

382 observed a robust, positive association between prey availability and snake foraging on a fine

383 scale partly because we could distinguish foraging site selection from other distinct behaviors

384 shaping site use. Previous snake telemetry studies accounting for prey availability have either

385 aggregated all snake relocations to compare seasonally within home ranges (e.g., Baxley \&

386 Qualls, 2009; Sperry \& Weatherhead, 2009; Michael et al., 2014) or against random or non-used

387 locations (Glaudas \& Rodríguez-Robles, 2011), rather than accounting for behavior-specific

388 variation in habitat use preferences.

Hoffman et al. (2020) found that site selection associated with foraging, ecdysis,

390 digestion, and gestation in this TRS population could be described by many of the landscape

391 variables used in this study (Table 1) at behavior-specific spatial scales (5-105 m). Foraging was

392 negatively associated with temperature and a landscape moisture gradient (indicating drier soils

393 and oak-dominated areas) and these conditions did not describe site use for other behaviors

394 (Hoffman et al., 2020, in review). Importantly, TRS foraging was associated with cooler

395 temperatures than sites associated with other behavioral states, suggesting foraging behavior may

396 be decoupled from snake thermoregulatory needs (Hoffman et al., 2020, in review). Our findings

397 that TRS foraging is associated with greater prey availability but also suboptimal conditions for

398 thermoregulation demonstrate that snakes preferentially seek out prey-rich areas to forage.

399 Habitat structure may therefore incompletely describe foraging behavior, and the prey landscape

400 is an important additional predictor of ambush site selection (Fig. 6). 
Our finding that the Cumulative Prey landscape, instead of any one prey species'

402 distribution, is strongly predictive of TRS foraging can be understood in the context of snake

403 foraging mode and dietary breadth. First, foraging site selection that maximizes encounters

404 across multiple prey species is likely partly due to the sit-and-wait foraging mode of most

405 viperids (Huey \& Pianka, 1981; Reinert et al., 1984). Predators using an ambush strategy to hunt

406 are more likely than widely foraging predators to prey on highly mobile species (i.e. species

407 more likely to be encountered), be non-selective in their prey choices, and therefore consume

408 prey species in proportion to their availability (Huey \& Pianka, 1981). Viperid species appear to

409 forage in a two-part process, in which snakes first search the surrounding landscape for a suitable

410 ambush site where prey may be more readily available, and then wait to encounter prey or

411 abandon the site when prey encounters are unlikely (Reinert et al., 1984; Clark, 2006). Clark

412 (2006) monitored foraging TRS with videography and demonstrated that snakes selected ambush

413 sites based on potential contact with multiple prey individuals of the same or a different species,

414 with snakes likely using prey chemical trails for identification of these fine-scale small mammal

415 hotspots. Our results also support that TRS may select ambush sites based on the detection of

416 multiple prey species (Clark, 2004).

418 habitat selection. The studies that have most conclusively linked snake space use to the

419 abundance of their prey examined focal snake species which primarily consumed a single prey

420 species (Madsen \& Shine, 1996; Heard et al., 2004). With increasing diet generalization, snakes

421 are expected to respond to total prey availability rather than the distribution of any one species

422 (Carfagno et al., 2006). This supports our finding that foraging in TRS, a species that primarily 
423 consumes small mammals but does not specialize on any species, positively correlates with the

424 overlapping distributions of multiple potential prey.

The orientation of TRS ambush, such as at log, non-log (i.e. forest floor), or vertical-tree, can suggest but not validate the potential prey species targeted through ambush (Reinert et al.,

427 2011; Goetz et al., 2016). Snakes are more likely to encounter mice and some squirrel species

428 (including Tamias striatus and S. carolinensis) across fallen logs (Douglass \& Reinert, 1982),

429 shrews and voles on the forest floor through leaf litter and vegetation (Reinert et al., 2011), and

430 S. carolinensis at standing trees (Goetz et al., 2016). An alternative explanation to TRS

431 prioritizing multiple prey chemical cues in ambush site selection is that by combining site-

432 specific prey encounter rates for multiple prey species, we negated any prey-specific preferences

433 by snakes. However, we do not believe this to be likely because we did not detect a difference in

434 predicted encounters of any prey species or combined prey grouping for observed snake foraging

435 sites among ambush orientations (e.g., snakes foraging at logs were not more likely to encounter

436 mice than in non-log ambush). Our finding of equally available prey opportunities among

437 ambush orientations further supports that prey identity is potentially less significant than overall

438 prey availability during foraging in this population (Supplementary Material).

Although Cumulative Prey emerged as the best-supported model for adults generally, we

440 also found some sex-specific differences in individual prey associations (Table S7). Mice most

441 reliably predicted female foraging (Fig. 7B), while chipmunks best predicted male foraging (Fig.

442 8B). Timber rattlesnakes exhibit an ontogenetic expansion in diet, with larger snakes (i.e. adult

443 males) able to consume larger prey and a broader diversity of small mammals but still target

444 smaller prey indiscriminately (Clark, 2002; Reinert et al., 2011). We must emphasize however

445 that we did not conduct diet analyses to examine the dietary compositions of snakes in our 
446 population, and diet has been shown to vary by population and region (Reinert et al., 2011;

447 Wittenberg, 2012; Goetz et al., 2016). We therefore caution against trying to infer dietary

448 patterns from the spatial overlap of snakes with individual prey species or from observed ambush

449 orientations (Clark, 2006; Reinert et al., 2011).

451 (Tamias striatus) or squirrels (Sciurus spp.), and accordingly, encounter rates for mice scaled

452 higher overall (Table 2; Fig. 3). Despite the prevalence of mice across our study area, their

453 distribution related very little to that of chipmunks (Pearson's r $=-0.19$ ) and squirrels (Pearson's

$454 \mathrm{r}=-0.10)$. Chipmunks and squirrel distributions were most correlated at the landscape scale

455 (Pearson's $r=0.3$ ). We captured squirrels on camera more intermittently than other rodents, but

456 they exhibited the most complex landscape-scale spatial relationships. Similar to mice and

457 chipmunks, squirrels preferred forest structural characteristics associated with mature forests,

458 including taller canopies and lower understory density, but uniquely with drier, southwestern-

459 facing slopes associated with oaks (Urban \& Swihart 2011).

We primarily considered spatial associations of small mammals, but we also observed

461 temporal shifts in availability (Figs 3A and 5A). Rodent encounter rates greatly increased

462 between the two sampled years (2017-2018), and year was the best predictor in the zero-inflated

463 process models for all species (Table S5). We believe this pattern likely corresponds to the

464 boom-bust mast cycles of oaks (Quercus spp.), beeches (Fagus spp.), and hickories (Carya spp.)

465 during 2016 and 2017 and the associated stimulus of increased food availability on rodent

466 population dynamics during the following year (Clotfelter et al., 2007). Given our rodent

467 encounter rate patterns, we suspect, but cannot confirm, that 2016 was a poor mast year and from

468 observational data, 2017 represented a better than average mast crop, particularly for black oaks 
(Quercus velutina) at the site (R. Snell, pers. comm.). We emphasize that we did not expect these

470 yearly fluctuations to affect snake spatial associations with small mammals because our

471 remotely-sensed landscape and forest structural characteristics did not change over the course of

472 the study.

Although our study provides a unique, fine-scale link between prey and predator space

474 use, there are some limitations to the inferences we can make. First, an important assumption to

475 behavioral observations during radio-telemetry is continuity in behavior. We monitored snakes

476 during the day and assumed that individuals remained in a behavioral state if we relocated them

477 at the same site and they exhibited the same behavioral state (e.g. ambush posture) across

478 multiple relocations. We therefore cannot account for temporal gaps in spatial data, during which

479 behavioral shifts or additional ambush site selection/abandonment and any nocturnal foraging

480 patterns may occur (Clark, 2006).

Our field deployment of camera traps was intended to simulate a snake's perspective and

482 represent a conceptual test of estimating prey availability for this species. Improvements to our

483 camera trap protocol would need to occur in any future applications, such as improving prey

484 species' detections and sampling more thoroughly and extensively across habitat types and snake

485 ambush sites specifically. Improved image quality could potentially enhance detection of rarely

486 captured, smaller prey, such as shrews and voles (Table 2). Additionally, we used daily species

487 occupancy to account for individual animals moving around or returning to camera sites within a

488 12-hr interval. Our prey availability metric underestimates true availability. However, we expect

489 this bias to be consistent across all habitats surveyed, which may not be the case in studies using

490 prey abundance as a proxy of availability (Carfagno et al., 2006; Sperry \& Weatherhead, 2009). 
We also made indirect spatial links between rodents and snakes as our camera locations

492 do not, for the most part, match known TRS foraging locations. We inferred prey availability at

493 snake ambush sites by projecting small mammal spatial relationships across the landscape, which

494 may incompletely capture the spatial heterogeneity of their distributions. However, we found our

495 remotely-sensed landscape-scale covariates (Table 1) to have moderately strong effects on rodent

496 encounter rates (Table 3). In future studies, we recommend direct quantification of small

497 mammal encounters at observed ambush sites and other selected behavior-specific sites to more

498 precisely link foraging behavior to prey spatial distributions.

499 Conclusions

$500 \quad$ Multiple factors could affect the relationship between prey availability and snake spatial

501 ecology, including prey behavior and habitat use, the spatial scales of study, snake diet and

502 foraging mode, and environmental fluctuations. We recognize that thermal requirements are the

503 underlying determinant of overall habitat use variation in snakes, but prey availability plays a

504 potentially important and underappreciated role in local habitat selection. We found a strong

505 association between TRS foraging site selection and rodent encounter rates. Our results suggest

506 that TRS can detect fine-scale differences in prey availability and spatially distribute themselves

507 accordingly. We demonstrate that optimal foraging theory may be applicable to the habitat

508 selection of a low-energy ambush predator.

\section{Acknowledgements}

510 We thank the Ohio Division of Wildlife for funding this project. B. Borovicka and the U. S.

511 Forest Service provided invaluable logistical support. We also thank T. Lacina, S. Stevens, B.

512 Hiner, E. Scott, and J. Myers for dedicated field work and data collection. 


\section{Authors' contributions}

514 A. S. H. \& W. E. P. designed methodology; A. S. H, J. L. B, \& Z. T. T. collected the data; A. M.

515 T. analyzed the data; A. M. T. led the writing of the manuscript. All authors contributed critically

516 to the drafts and gave final approval for publication.

\section{Data Availability Statement}

518 Data will be made available from the Figshare Digital Repository.

\section{ORCID}

520 Annalee M. Tutterow https://orcid.org/0000-0001-8639-1097

521 William E. Peterman https://orcid.org/0000-0001-5229-9268 


\section{References}

523

524

525

Aber, J. D. (1979). Foliage-height profiles and succession in northern hardwood forests. Ecology, $60,18-23$.

Adams, B. T., \& Matthews, S. N. (2018). Enhancing forest and shrubland mapping in a managed forest landscape with Landsat-Lidar data fusion. Natural Areas Journal, 38, 402-418.

Adams, B. T., Matthews, S. N., Peters, M. P., Prasad, A. \& Iverson, L. R. (2019). Mapping floristic gradients of forest composition using an ordination-regression approach with landsat OLI and terrain data in the Central Hardwoods region. Forest Ecology and Management, 434, 87-98.

Beers, T. W., Dress, P. E., \& Wensel, L. C. (1966). Notes and observations: Aspect transformation in site productivity research. Journal of Forestry, 64, 691-692.

Blouin-Demers, G., \& Weatherhead, P. J. (2001). An experimental test of the link between foraging, habitat selection and thermoregulation in black rat snakes Elaphe obsoleta obsoleta. Journal of Animal Ecology, 70, 1006-1013.

Bürkner, P. (2017). brms: An R package for Bayesian multilevel models using Stan. Journal of Statistical Software, 80, 1-28.

Baxley, D. L., \& Qualls, C. P. (2009). Black pine snake (Pituophis melanoleucus lodingi): spatial ecology and associations between habitat use and prey dynamics. Journal of Herpetology, 43, 284-293.

Beaupre, S. J. (2008). Annual variation in time-energy allocation by timber rattlesnakes (Crotalus horridus) in relation to food acquisition. In W. K. Hayes, K.R. Beaman, M.D. Cardwell, \& S.P. Bush (Eds.), Biology of the Rattlesnakes (pp. 111-122). Loma Linda, California, USA: Loma Linda University Press. 
545 Carfagno, G. L. F., Heske, E. J., \& Weatherhead, P. J. (2006). Does mammalian prey abundance

546 explain forest-edge use by snakes? Écoscience, 13, 293-297.

547 Charnov, E. L. (1976). Optimal foraging, the marginal value theorem. Theoretical Population

$548 \quad$ Biology, 9,129-136.

549 Clark, R. W. (2002). Diet of the timber rattlesnake, Crotalus horridus. Journal of Herpetology,

$550 \quad 36,494-499$.

551 Clark, R. W. (2004). Timber rattlesnakes (Crotalus horridus) use chemical cues to select ambush sites. Journal of Chemical Ecology, 30, 607-617.

553 Clark, R. W. (2006). Fixed videography to study predation behavior of an ambush foraging snake, Crotalus horridus. Copeia, 2006, 181-187.

555 Clotfelter, E. D., Pedersen, A. B., Cranford, J. A., Ram, N., Snajdr, E. A., Nolan, V., Ketterson, E. D. (2007). Acorn mast drives long-term dynamics of rodent and songbird populations.

Douglass, N. J., \& Reinert, H. K. (1982). The utilization of fallen logs as runways by small mammals. Proceedings of the Pennsylvania Academy of Science, 56, 162-164.

560 Flaxman, S. M., \& Lou, Y. (2009). Tracking prey or tracking the prey's resource? Mechanisms of movement and optimal habitat selection by predators. Journal of Theoretical Biology,

563 Glaudas, X., \& Rodríguez-Robles, J. A. (2011). A two-level problem: habitat selection in relation to prey abundance in an ambush predator, the speckled rattlesnake (Crotalus mitchellii). Behaviour, 148, 1491-1524.

Glaudas, X., \& Alexander, G. J. (2017). Food supplementation affects the foraging ecology of a low-energy, ambush-foraging snake. Behavioral Ecology and Sociobiology, 71, 1-11. 
Goetz, S. M., Petersen, C. E., Rose, R. K., Kleopfer, J. D., \& Savitzky, A. H. (2016). Diet and foraging behaviors of timber rattlesnakes, Crotalus horridus, in eastern Virginia. Journal of Herpetology, 50, 520-526.

571

572

573

574

575

576

577

578

579

Hammond, J. I., Luttbeg, B., Brodin, T., \& Sih, A. (2012). Spatial scale influences the outcome of the predator-prey space race between tadpoles and predatory dragonflies: Scale and predator-prey games. Functional Ecology, 26, 522-531.

Harvey, D. S., \& Weatherhead, P. J. (2006). A test of the hierarchical model of habitat selection using eastern massasauga rattlesnakes (Sistrurus catenatus). Biological Conservation, 130, 206-216.

Heard, G. W., Black, D., \& Robertson, P. (2004). Habitat use by the inland carpet python (Morelia spilota metcalfei): Seasonal relationships with habitat structure and prey distribution in a rural landscape. Austral Ecology, 29, 446-460.

Hijmans, R. J. (2020). Raster: geographic data analysis and modeling. R Package Version 3.3-13. <http://CRAN.R-project.org/package=raster $>$.

Hopcraft, J. G. C., Sinclair, A. R. E., \& Packer, C. (2005). Planning for success: Serengeti lions seek prey accessibility rather than abundance. Journal of Animal Ecology, 74, 559-566.

Huey, R. B., \& Pianka, E. R. (1981). Ecological consequences of foraging mode. Ecology, 62, 991-999.

Johnson, D. H. (1980). The comparison of usage and availability measurements for evaluating resource preference. Ecology, 61, 65-71.

Kittle, A. M., Anderson, M., Avgar, T., Baker, J. A., Brown, G. S., Hagens, J., ... Fryxell, J. M. (2017). Landscape-level wolf space use is correlated with prey abundance, ease of mobility, and the distribution of prey habitat. Ecosphere, 8, e01783. 
Madsen, T., \& Shine, R. (1996). Seasonal migration of predators and prey-A study of pythons and rats in tropical Australia. Ecology, 77, 149-156.

Martin, T. G., Wintle, B. A., Rhodes, J. R., Kuhnert, P. M., Field, S. A., Low-Choy, S. J., ... Possingham, H. P. (2005). Zero tolerance ecology: improving ecological inference by modelling the source of zero observations. Ecology Letters, 8, 1235-1246.

Mayor, S. J., Schneider, D. C., Schaefer, J. A., \& Mahoney, S. P. (2009). Habitat selection at multiple scales. Ecoscience, 16, 238-247.

McNeill, E. P., Thompson, I. D., Wiebe, P. A., Street, G. M., Shuter, J., Rodgers, A. R., \& Fryxell, J. M. (2020). Multi-scale foraging decisions made by woodland caribou (Rangifer tarandus caribou) in summer. Canadian Journal of Zoology, 98, 331-341.

Michael, D. R., Cunningham, R. B., Macgregor, C., Brown, D., \& Lindenmayer, D. B. (2014). The effects of prey, habitat heterogeneity and fire on the spatial ecology of peninsular diamond pythons (Morelia spilota spilota). Austral Ecology, 39, 181-189.

Moore, J. A., \& Gillingham, J. C. (2006). Spatial ecology and multi-scale habitat selection by a threatened rattlesnake. Copeia, 2006, 742-751.

606 Nelson, D. L., Kellner, K. F., \& Swihart, R. K. (2019). Rodent population density and survival respond to disturbance induced by timber harvest. Journal of Mammalogy, 100, 12531262. State Forest. <http://forestry.ohiodnr.gov/vintonfurnace>.

611 Piironen, J., \& Vehtari, A. (2017). Comparison of Bayesian predictive methods for model selection. Statistics and Computing, 27, 711-735. 
613 R Core Team. (2020). R: A language and environment for statistical computing. Version 3.6.1. R Foundation for Statistical Computing, Vienna, Austria. <https://www.R-project.org/>.

Reinert, H. K., Cundall, D., \& Bushar, L. M. (1984). Foraging behavior of the timber rattlesnake, Crotalus horridus. Copeia, 1984, 976-981.

Reinert, H. K., MacGregor, G. A., Esch, M., Bushar, L. M., \& Zappalorti, R. T. (2011). Foraging ecology of timber rattlesnakes, Crotalus horridus. Copeia, 2011, 430-442.

Schooler, S. L., \& Zald, H. S. J. (2019). Lidar prediction of small mammal diversity in Wisconsin, USA. Remote Sensing, 11(19), 2222.

Simonson, W. D., Allen, H. D., \& Coomes, D. A. (2014). Applications of airborne lidar for the assessment of animal species diversity. Methods in Ecology and Evolution, 5, 719-729.

Sperry, J. H., and P. J. Weatherhead. (2009). Does prey availability determine seasonal patterns of habitat selection in Texas ratsnakes. Journal of Herpetology, 43, 55-64.

Sutton, W. B., Wang, Y., Schweitzer, C. J., \& McClure, C. J. W. (2017). Spatial ecology and multi-scale habitat selection of the Copperhead (Agkistrodon contortrix) in a managed forest landscape. Forest Ecology and Management, 391, 469-481.

Tetzlaff, S. J., Carter, E. T., DeGregorio, B. A., Ravesi, M. J., \& Kingsbury, B. A. (2017). To forage, mate, or thermoregulate: Influence of resource manipulation on male rattlesnake regeneration in southern Indiana. Forest Ecology and Management, 261, 353-361. 
636 Williams, A. C., Flaherty, S. E., \& Flaxman, S. M. (2013). Quantitative tests of multitrophic 637 ideal free distribution theory. Animal Behaviour, 86, 577-586.

638 Wittenberg, R. D. (2012). Foraging ecology of the timber rattlesnake (Crotalus horridus) in a 639 fragmented agricultural landscape. Herpetological Conservation and Biology, 7, 449$640 \quad 461$.

641 Womble, J. N., Sigler, M. F., \& Willson, M. F. (2009). Linking seasonal distribution patterns 642 with prey availability in a central-place forager, the Steller sea lion. Journal of Biogeography, 36, 439-451.

644 Zuur, A. F., Ieno, E. N., Walker, N. J., Saveliev, A. A., \& Smith, G. M. (2009). Mixed effects models and extensions in ecology with R. Springer, New York, New York, USA. 
648 Table 1. Fine-scale $(5-\mathrm{m})$ landscape covariates $(\mathrm{n}=16)$ used to describe small mammal spatial 649 distributions in a mixed-use forest in southeastern Ohio. Summary statistics for each continuous 650 variable provide the mean value $( \pm$ SD) and range of values across 242 camera trap sites.

\begin{tabular}{|c|c|c|c|}
\hline Type & Variable & Description/Interpretation & $\begin{array}{l}\text { Summary } \\
\text { Statistics } \\
\text { (Mean } \pm \mathrm{SD} \text {, } \\
\quad \text { range) }\end{array}$ \\
\hline \multirow{2}{*}{$\begin{array}{c}\text { Forest } \\
\text { Management }\end{array}$} & $\begin{array}{c}\text { Presence of burns } \\
\text { (Burn) }\end{array}$ & $\begin{array}{l}\text { Presence/absence of burned stands } \\
\text { (No. camera sites). }\end{array}$ & $\begin{array}{c}\text { Burns }=31 \\
\text { Non-burns = } \\
211\end{array}$ \\
\hline & Stand age (Age) & $\begin{array}{l}\text { Approximate stand age (years), } \\
\text { reflecting forest management } \\
\text { activity. }\end{array}$ & $\begin{array}{c}72 \pm 47 \\
4-151\end{array}$ \\
\hline \multirow{4}{*}{ Topography } & $\begin{array}{l}\text { Beers' transformed } \\
\text { aspect index } \\
\text { (Beers) }\end{array}$ & $\begin{array}{l}\text { Transforms circular aspect to a } \\
\text { range representing xeric southwest } \\
\text { aspects to mesic northeast aspects. }\end{array}$ & $\begin{array}{c}0.95 \pm 0.69 \\
0-2\end{array}$ \\
\hline & Elevation (DEM) & $\begin{array}{l}\text { LiDAR-derived Digital Terrain } \\
\text { Model }(\mathrm{m}) \text {. }\end{array}$ & $\begin{array}{l}258.4 \pm 18.5 \\
203-292\end{array}$ \\
\hline & Slope & Slope (degrees). & $\begin{array}{l}15.3 \pm 7.6 \\
0-36.9\end{array}$ \\
\hline & $\begin{array}{l}\text { Stream distance } \\
\quad(\text { Stream })\end{array}$ & Distance to the nearest stream (m). & $\begin{array}{l}154 \pm 91 \\
1-381\end{array}$ \\
\hline \multirow{2}{*}{$\begin{array}{l}\text { Multipurpose } \\
\text { Ordination } \\
\text { Axes }\end{array}$} & $\begin{array}{l}\text { NMDS axis } 1 \text { of } \\
\text { floristic variation } \\
\quad(\mathrm{NMDS} 1)\end{array}$ & $\begin{array}{l}\text { Ordination axis representing a } \\
\text { moisture and topographic gradient. } \\
\text { Large, negative values represent } \\
\text { drier southwestern facing slopes } \\
\text { and positive values represent } \\
\text { floodplains. }\end{array}$ & $\begin{array}{c}-0.006 \pm 0.236 \\
-0.516-0.981\end{array}$ \\
\hline & $\begin{array}{l}\text { NMDS axis } 2 \text { of } \\
\text { floristic variation } \\
\quad(\mathrm{NMDS} 2)\end{array}$ & $\begin{array}{l}\text { Ordination axis representing a } \\
\text { forest structural and successional } \\
\text { gradient. Large, positive values are } \\
\text { associated with taller canopies and } \\
\text { mature forests. }\end{array}$ & $\begin{array}{c}-0.048 \pm 0.199 \\
-0.760-0.420\end{array}$ \\
\hline
\end{tabular}




\begin{tabular}{|c|c|c|c|}
\hline \multirow{8}{*}{$\begin{array}{l}\text { Vegetation } \\
\text { Structure \& } \\
\text { Composition }\end{array}$} & $\begin{array}{l}\text { Canopy surface } \\
\text { height }(\mathrm{CHM})\end{array}$ & $\begin{array}{l}\text { Canopy height model representing } \\
\text { the maximum canopy height }(\mathrm{m}) \text {. }\end{array}$ & $\begin{array}{l}16.3 \pm 10.7 \\
0-40\end{array}$ \\
\hline & $\begin{array}{l}\text { MacArthur's } \\
\text { Foliage Height } \\
\text { Diversity (FHD) }\end{array}$ & $\begin{array}{l}\text { Shannon's diversity of vegetation } \\
\text { hits throughout the vertical profile } \\
\text { ( } 3 \text { vertical layers, } 0-5,5-25 \text {, and } \\
>25 \text { m) of each point location. }\end{array}$ & $\begin{array}{l}0.70 \pm 0.26 \\
0-1.04\end{array}$ \\
\hline & $\begin{array}{l}\text { Enhanced } \\
\text { vegetation } \\
\text { index }(E V I)\end{array}$ & $\begin{array}{l}\text { Vegetation "greenness" or } \\
\text { productivity. }\end{array}$ & $\begin{array}{c}0.703 \pm 0.109 \\
0.095-0.878\end{array}$ \\
\hline & $\begin{array}{l}\text { Plant species } \\
\text { richness }(\mathrm{PSR})\end{array}$ & Number of woody plant taxa. & $\begin{array}{c}14.6 \pm 1.5 \\
7.8-18.7\end{array}$ \\
\hline & $\begin{array}{l}\text { Overstory density } \\
\text { (OVE) }\end{array}$ & $\begin{array}{l}\text { Amount of overstory (i.e., } \geq 8-\mathrm{cm} \\
\mathrm{DBH}) \text { foliage (stems/ha). }\end{array}$ & $\begin{array}{l}18.5 \pm 24.2 \\
0-132.2\end{array}$ \\
\hline & $\begin{array}{l}\text { Understory density } \\
\text { (UND) }\end{array}$ & $\begin{array}{l}\text { Amount of understory }(<8-\mathrm{cm} \\
\mathrm{DBH}) \text { foliage (stems/ha). }\end{array}$ & $\begin{array}{c}164.2 \pm 37.9 \\
41.9-316.6\end{array}$ \\
\hline & Tree density (TDE) & $\begin{array}{l}\text { Combined density of overstory and } \\
\text { understory size classes of woody } \\
\text { plants (stems/ha) }\end{array}$ & $\begin{array}{c}444.7 \pm 130.5 \\
56.3-954.6\end{array}$ \\
\hline & $\begin{array}{l}\text { Skewness of LiDAR } \\
\text { returns }(\mathrm{SKE})\end{array}$ & $\begin{array}{l}\text { Metric representing forest } \\
\text { succession. Skewness of LiDAR } \\
\text { returns is expected to be greater } \\
\text { (i.e., longer tail) for mature stands } \\
\text { compared to younger stands. }\end{array}$ & $\begin{array}{l}0.93 \pm 1.18 \\
-0.06-8.45\end{array}$ \\
\hline
\end{tabular}


653 Table 2. Camera trap $(n=242)$ daily detections of potential prey items for timber rattlesnakes 654 (Crotalus horridus) in a mixed-use forest in southeastern Ohio from 2017-2018. Bird detections 655 include common woodland residents, such as wood thrushes (Hylocichla mustelina), ovenbirds 656 (Seiurus aurocapilla), and Carolina wrens (Thryothorus ludovicianus).

\begin{tabular}{llll}
\hline & $\begin{array}{l}\text { Sites with } \\
\geq 1 \text { Detection }\end{array}$ & $\begin{array}{l}\text { Sites with } \\
>\text { 1 Detection }\end{array}$ & $\begin{array}{l}\text { Maximum } \\
\text { Detections (Days) }\end{array}$ \\
\hline $\begin{array}{l}\text { Mice } \\
\begin{array}{l}\text { (Peromyscus } \text { spp.) } \\
\text { Eastern chipmunks }\end{array}\end{array}$ & $148(61 \%)$ & $86(36 \%)$ & 17 \\
$\begin{array}{l}\text { (Tamias striatus) } \\
\text { Squirrels } \\
\text { (Sciurus spp.) }\end{array}$ & $89(37 \%)$ & $48(20 \%)$ & 9 \\
$\begin{array}{l}\text { Shrews } \text { (Soricidae) } \\
\text { Voles }\end{array}$ & $14(6 \%)$ & $15(6 \%)$ & 6 \\
$\begin{array}{l}\text { Microtus spp.) } \\
\text { Eastern cottontails } \\
\text { Sylvilagus floridanus) }\end{array}$ & $25(10 \%)$ & $2(0.8 \%)$ & 2 \\
Birds & $124(51 \%)$ & 0 & 1 \\
\hline
\end{tabular}


658 Table 3. Bayesian zero-inflated ( $\mathrm{Zi}$ ) negative binomial models of mice (Peromyscus spp.), 659 chipmunk (Tamias striatus), and squirrel (Sciurus spp.) encounter rates across 242 camera sites 660 in a mixed-use forest in southeastern Ohio. We modeled the number of camera days with a 661 species detection, offset by the total number of active camera days, as a function of study year 662 (2017-2018) and remotely-sensed landscape variables (5-m resolution). We report the variables 663 that best described each species' distribution. Mean coefficient estimates, standard errors $( \pm$ S.E.) 664 and percentage of the posterior distributions overlapping zero are provided. Refer to Table 1 for 665 further descriptions of covariates.

\begin{tabular}{|c|c|c|c|}
\hline & Mice & Chipmunks & Squirrels \\
\hline Year & $\begin{array}{l}0.56( \pm 0.17) \\
<1 \%\end{array}$ & & $\begin{array}{l}1.05( \pm 0.31) \\
<1 \%\end{array}$ \\
\hline Burn & $\begin{array}{l}-0.52( \pm 0.19) \\
<1 \%\end{array}$ & & \\
\hline Age & $\begin{array}{l}-0.09( \pm 0.06) \\
7 \%\end{array}$ & & \\
\hline Slope & & $\begin{array}{l}0.19( \pm 0.09) \\
3 \%\end{array}$ & \\
\hline NMDS1 & & & $\begin{array}{l}-0.24( \pm 0.14) \\
4 \%\end{array}$ \\
\hline NMDS 2 & & $\begin{array}{l}0.27( \pm 0.10) \\
<1 \%\end{array}$ & $\begin{array}{l}0.38( \pm 0.17) \\
1 \%\end{array}$ \\
\hline PSR & & $\begin{array}{l}0.23( \pm 0.11) \\
2 \%\end{array}$ & \\
\hline FHD & & & $\begin{array}{l}-0.41( \pm 0.22) \\
3 \%\end{array}$ \\
\hline OVE & & & $\begin{array}{l}0.3( \pm 0.14) \\
2 \%\end{array}$ \\
\hline UND & & & $\begin{array}{l}-0.4( \pm 0.17) \\
1 \%\end{array}$ \\
\hline $\begin{array}{l}Z i: \text { (Median camera } \\
\text { deployment date) })^{2}\end{array}$ & & & $\begin{array}{l}-1.52( \pm 1.16) \\
5 \%\end{array}$ \\
\hline Zi: Year & $\begin{array}{l}-3.56( \pm 2.09) \\
1 \%\end{array}$ & $\begin{array}{l}-4.02( \pm 2.04) \\
0\end{array}$ & $\begin{array}{l}1.21( \pm 2.8) \\
30 \%\end{array}$ \\
\hline
\end{tabular}




\section{$667 \quad$ Figures}
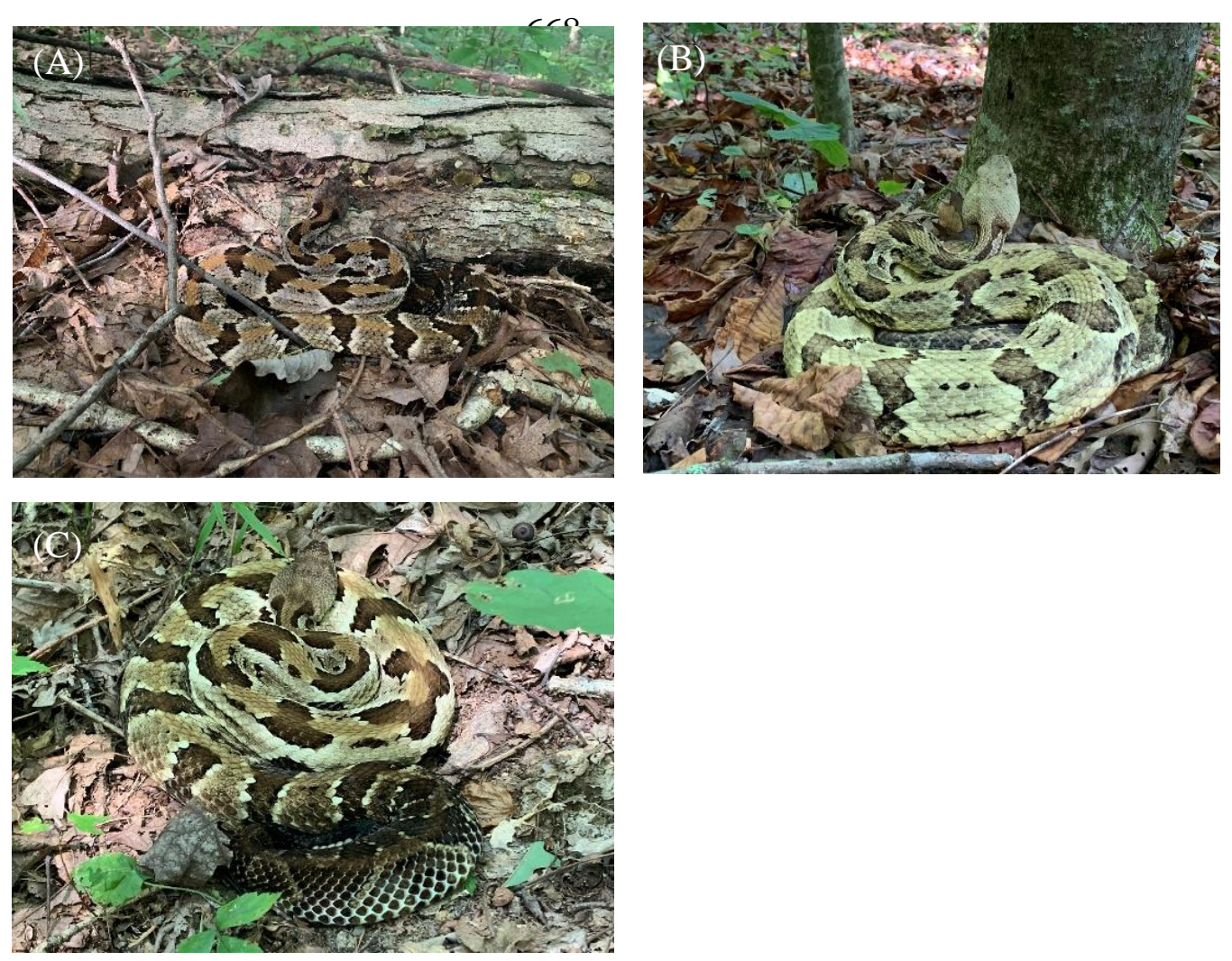

681 Figure 1. Characteristic ambush posture of timber rattlesnakes (Crotalus horridus) used to

682 identify foraging locations, including (A) foraging at logs and downed woody debris, (B)

683 vertical-tree foraging, and (C) non-log foraging along the forest floor. Snakes maintain a tight,

684 "S"-shaped coil regardless of foraging orientation. 

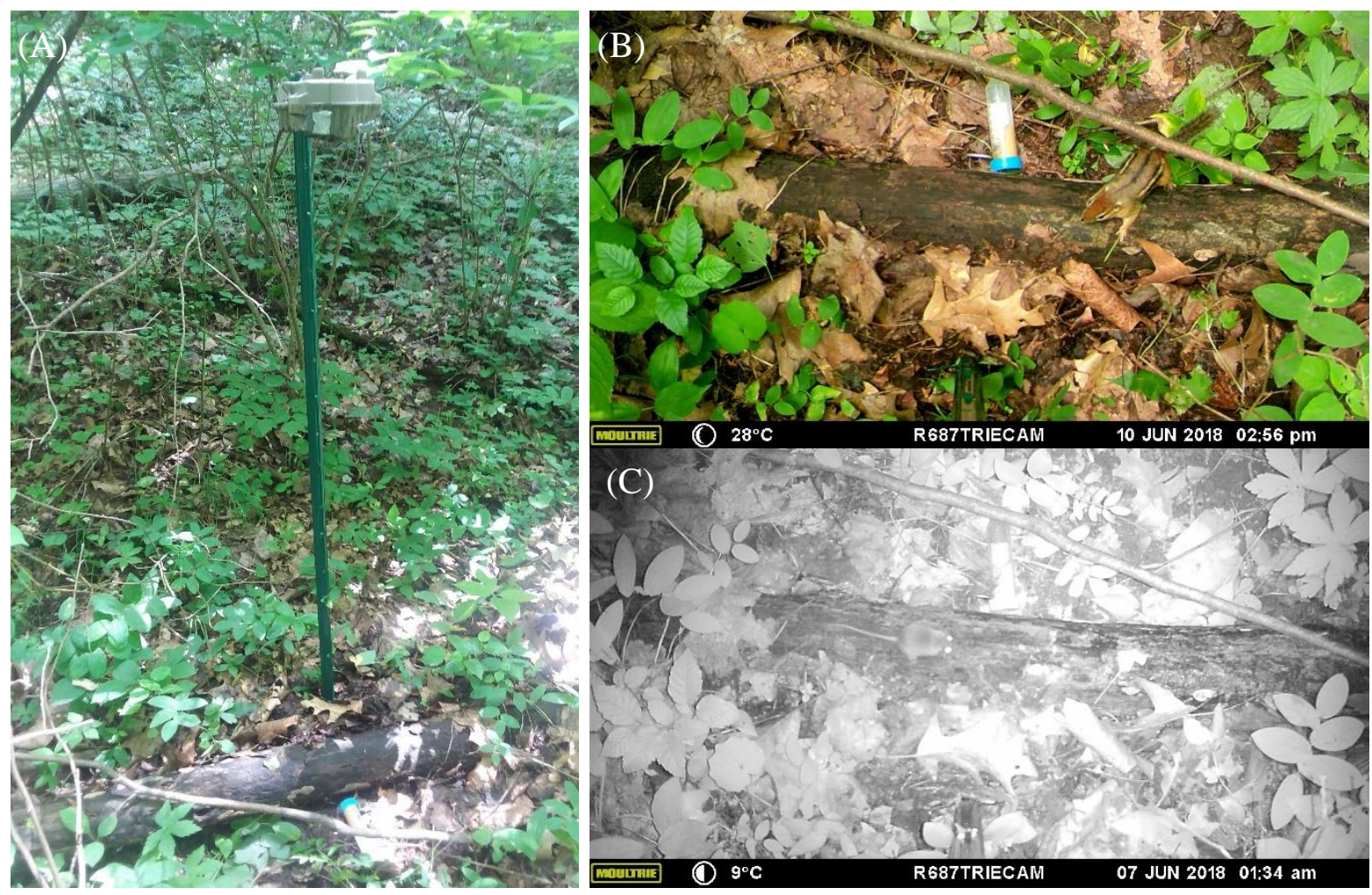

686 Figure 2. (A) Placement of a camera trap with bait for small mammals one meter above and 687 directly overlooking a log in a mature forest site in southeastern Ohio. (B) Tamias striatus and 688 (C) Peromyscus spp. captured on camera at this trap site. 

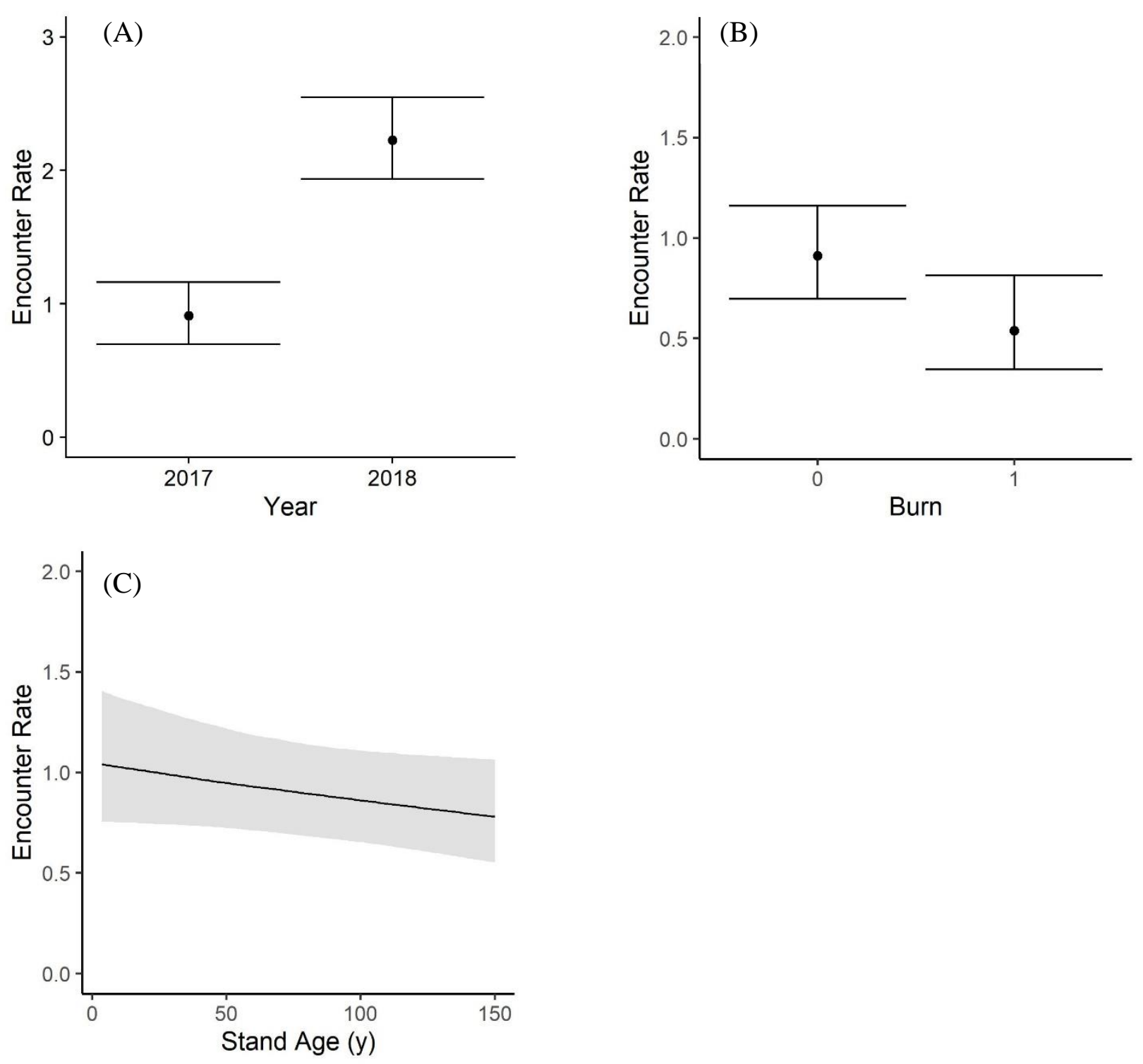

689 Figure 3. Daily estimated mice (Peromyscus spp.) encounter rates from 242 camera trap sites 690 distributed in a mixed-use forest in southeastern Ohio. 

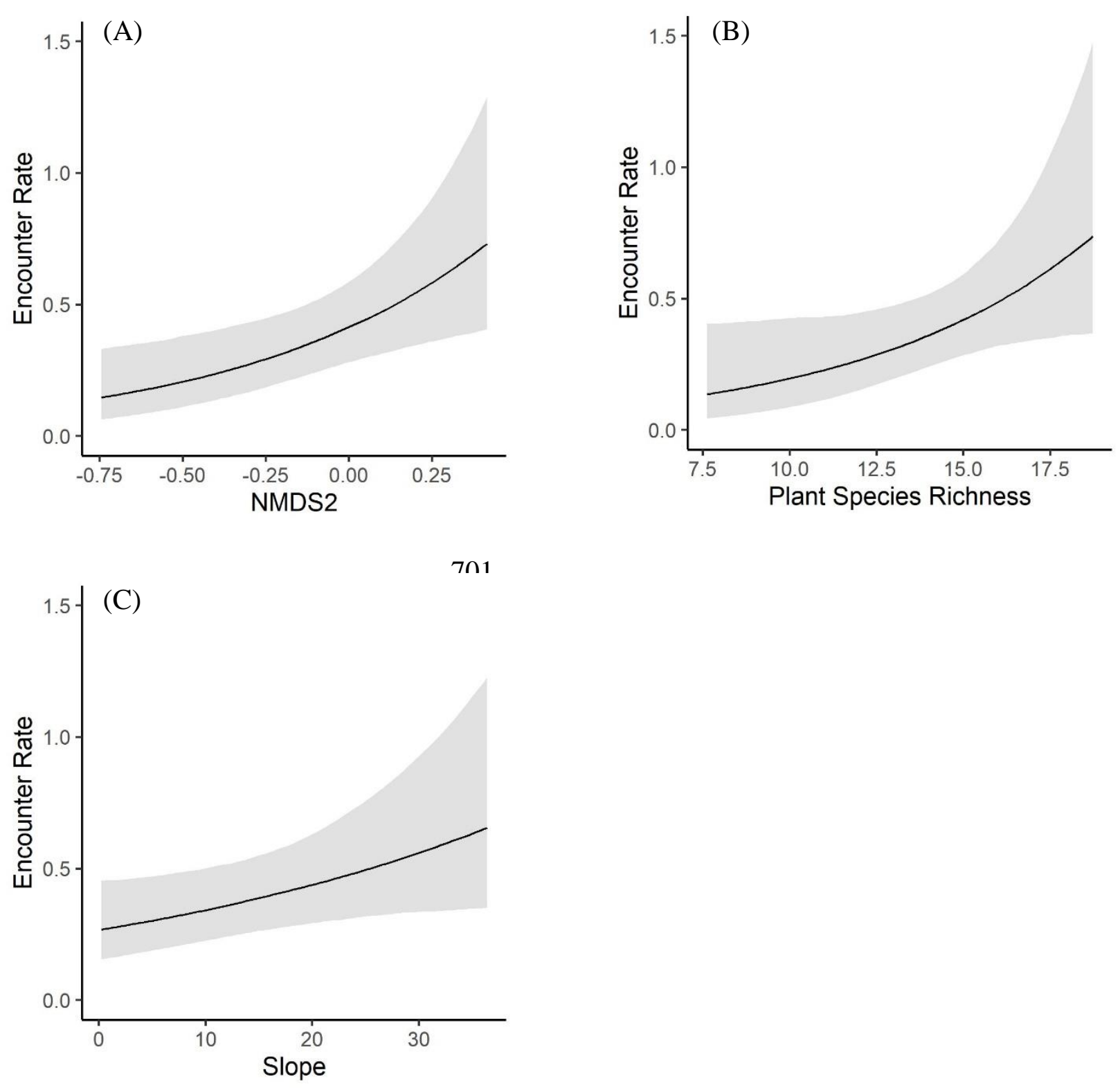

711 Figure 4. Daily estimated chipmunk (Tamias striatus) encounter rates from 242 camera trap sites 712 distributed in a mixed-use forest in southeastern Ohio. 

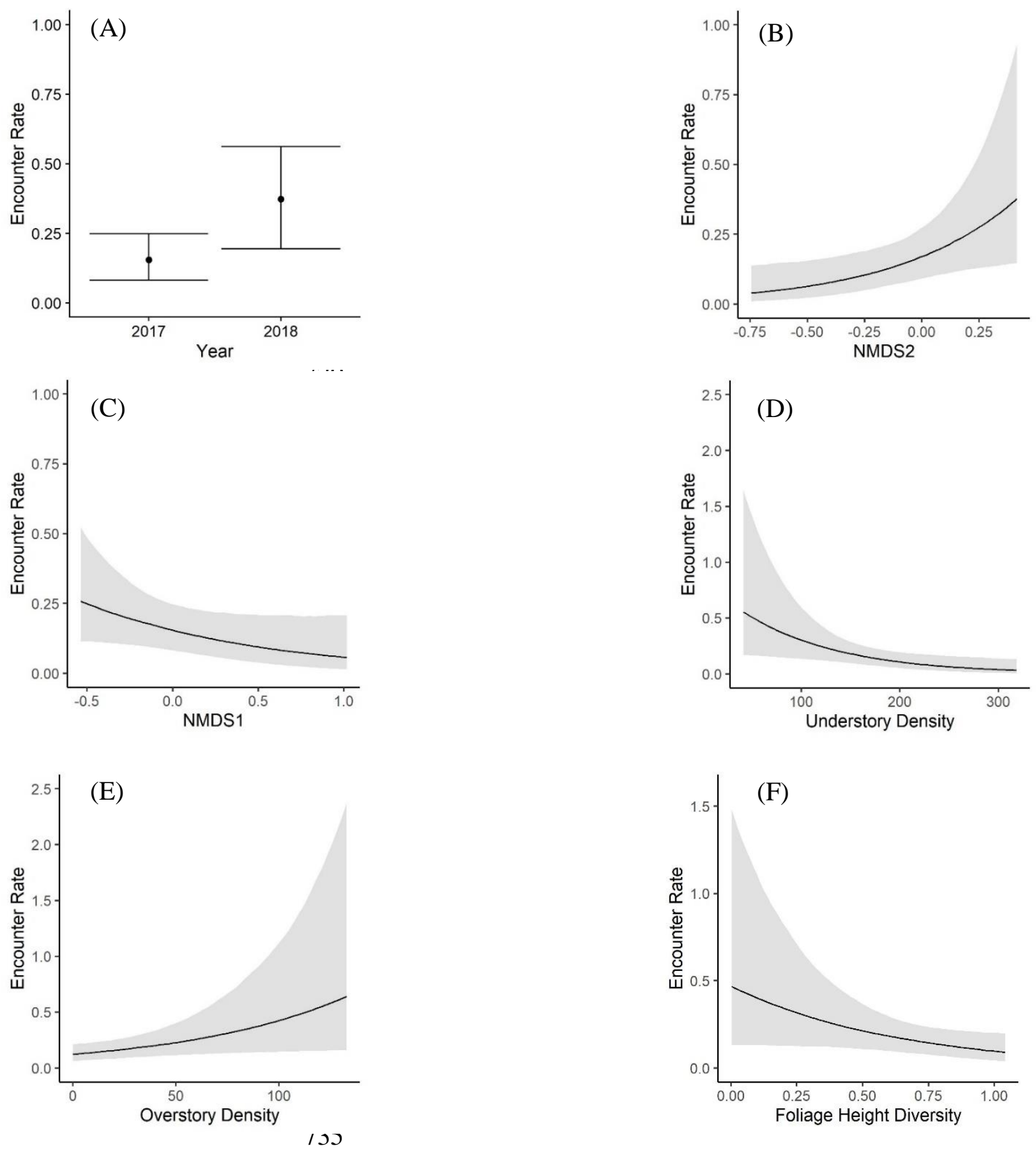

736 Figure 5. Daily estimated squirrel (Sciurus spp.) encounter rates from 242 camera trap sites 737 distributed in a mixed-use forest in southeastern Ohio. 


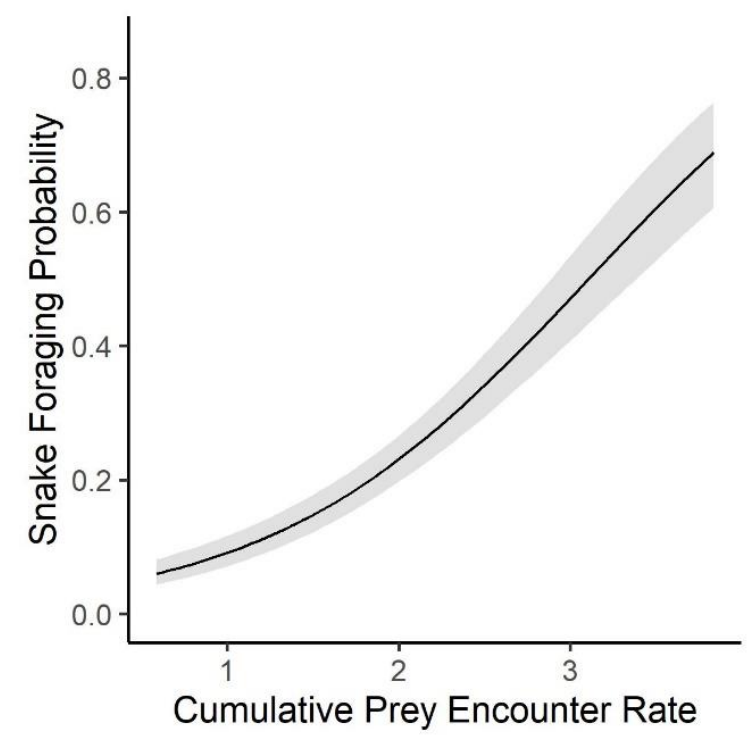

739 Figure 6. Foraging probability of 37 adult timber rattlesnakes (Crotalus horridus) in a mixed-use 740 forest in southeastern Ohio predicted by the cumulative contribution of estimated site-specific, 741 daily encounters with mice (Peromyscus spp.), chipmunks (Tamias striatus), and squirrels 742 (Sciurus spp.) from 2016-2019. 

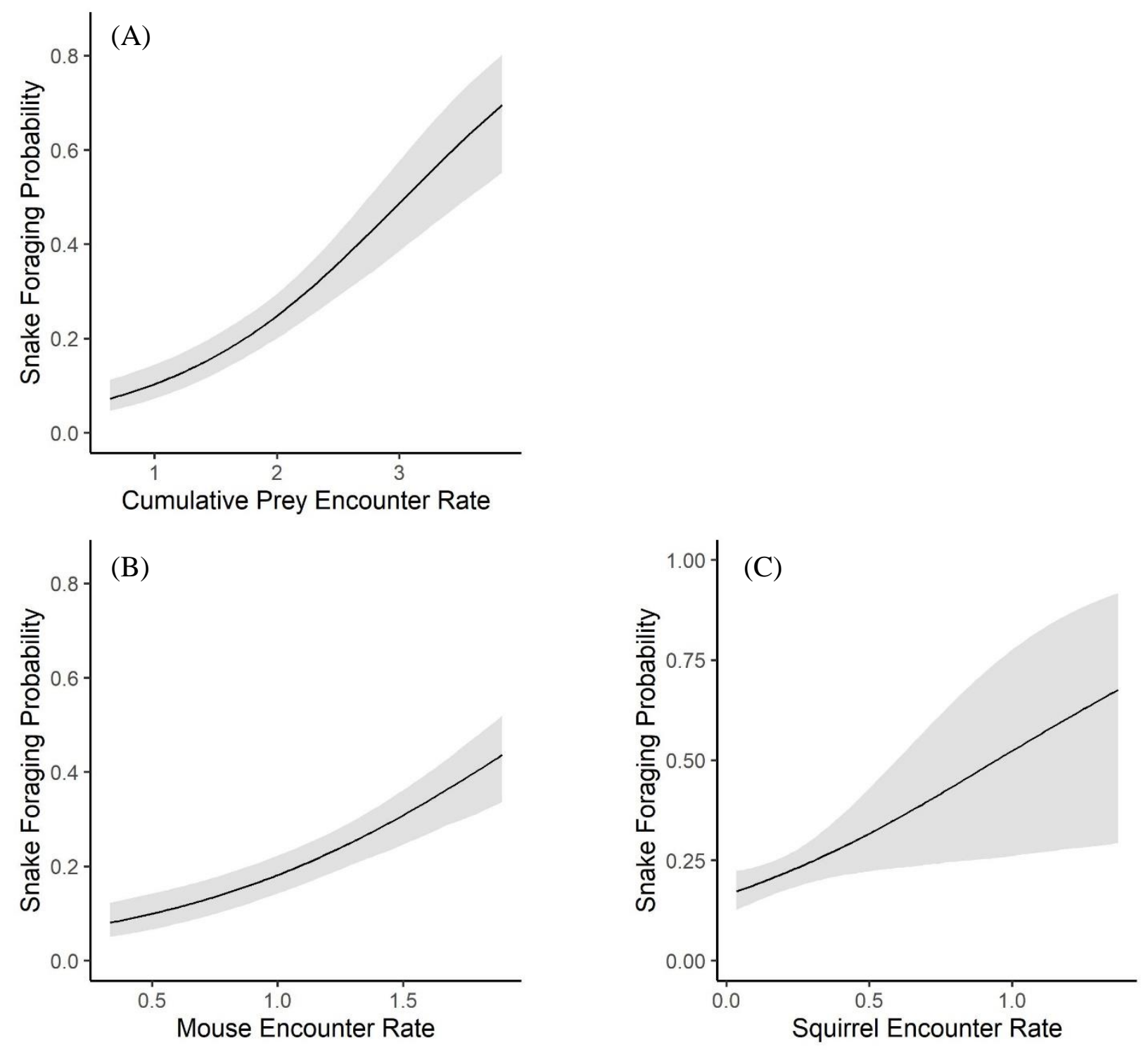

762

763 Figure 7. Adult female $(\mathrm{n}=16)$ timber rattlesnake (Crotalus horridus) foraging probabilities in a

764 mixed-use forest in southeastern Ohio predicted by prey encounter rates from 2016-2019. A)

765 Cumulative Prey encounter rate, representing the additive combination of mouse (Peromyscus

766 spp.), chipmunk (Tamias striatus), and squirrel (Sciurus spp.) site-specific encounter rates; B)

767 mice-specific encounter rate; and C) squirrel-specific encounter rate. 


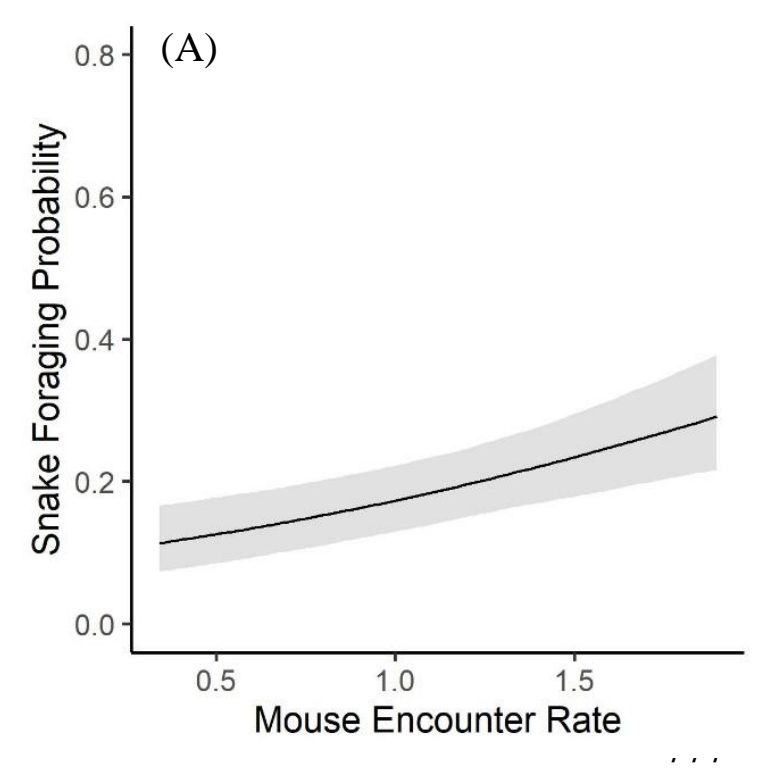

778

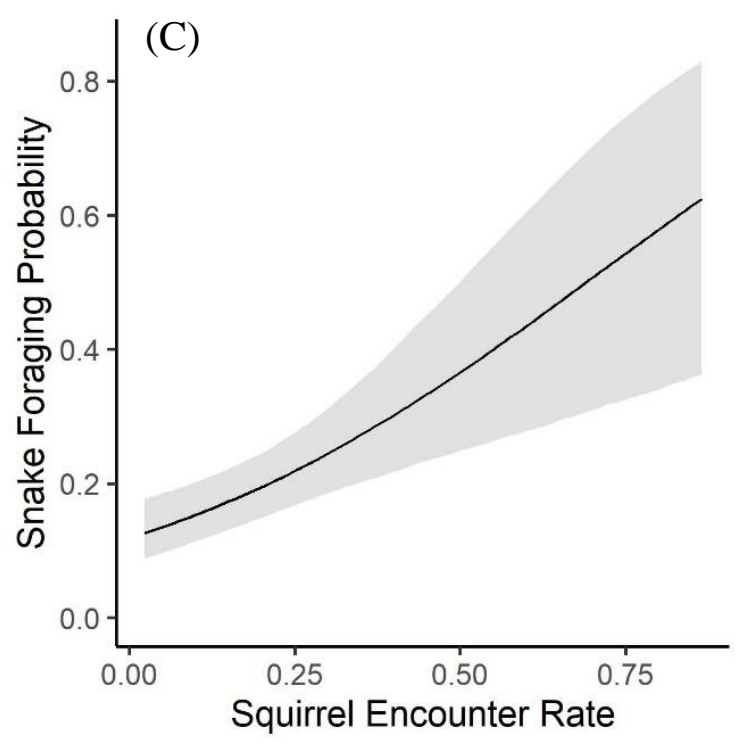

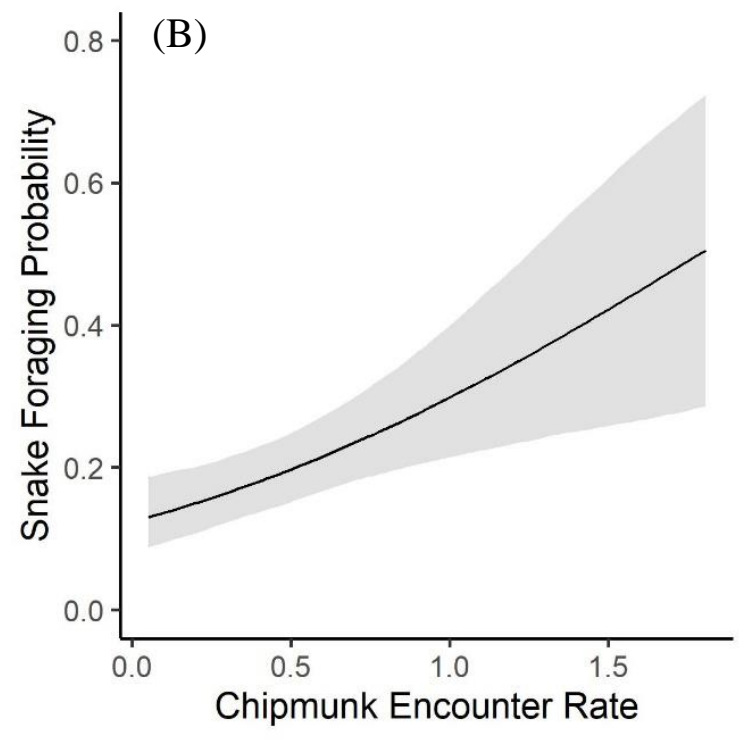

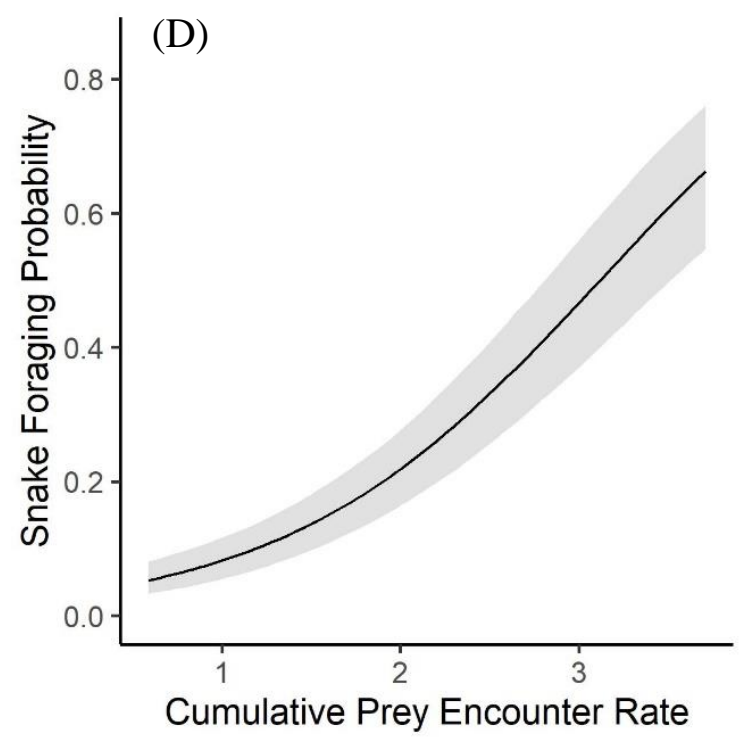

779 Figure 8. Adult male $(\mathrm{n}=21)$ timber rattlesnake (Crotalus horridus) foraging probabilities in a

780 mixed-use forest in southeastern Ohio predicted by prey encounter rates from 2016-2019. Prey781 specific foraging models include encounters with A) mice (Peromyscus spp.), B) chipmunks

782 (Tamias striatus), and C) squirrels (Sciurus spp.). D) Cumulative Prey encounter rate,

783 representing the additive combination of mouse, chipmunk, and squirrel site-specific encounter 784 rates. 